\title{
Óvodások IKT-használata otthon - szülői minta és szerepvállalás
}

\author{
Hódi Ágnes, ${ }^{*}$ Tóth Edit, ${ }^{* *}$ B. Németh Mária*** és Fáyné Dombi Alice ${ }^{* * * *}$
}

Az IKT-eszközök térnyerésével párhuzamosan megnövekedett az infokommunikációs technológiák használatát és azok különböző területekre gyakorolt hatásának vizsgálatát középpontba helyező kutatások száma. E kutatások min táit leginkább az iskoláskorúak és az annál idősebbek alkották, az óvodáskorúakra vonatkozóan alig vannak információink, a hazai óvodáskorúak és szüleik eszközhasználatáról nagymintás vizsgálatból származó aktuális adatok nem állnak rendelkezésre. Ez motivált bennünket arra, hogy egy kérdöives vizsgálat keretében adatokat gyújtsünk arra vonatkozóan, hogy az óvodáskorú gyermekek milyen IKT-eszközöket használnak, milyen rendszerességgel, mennyi ideig, illetve milyen szülői kontrollal teszik azt. Továbbá arra is kíváncsiak voltunk, hogy a szülő iskolai végzettségével repre zentált családi háttér milyen kapcsolatot mutat a gyermekek IKT-használatával. Eredményeink megmutatták, hogy a vizsgált óvodáskorú gyermekek döntő többsége technologizált háztartásban nő fel, és egy részük maga is rendelkezik IKT-eszközzel. Ebben a korosztályban még nem jellemző a napi szintű eszközhasználat, azonban a szülök válaszai rámutattak arra, hogy a fogyasztott tartalmak igen széles skálán mozognak. A szülök válaszai leképezik az évek óta tartó vitát az eszközök vélt vagy valós, jótékony vagy káros hatásáról, hiszen a vizsgált gyermekek egy része egyáltalán nem használ IKT-eszközt, annak ellenére, hogy azokból legalább egy darab van minden háztartásban. Adataink megmutatták, hogy a gyermek eszközhasználatának engedélyezése, illetve annak idötartama, gyakorisága nem, azonban a szülöi kontroll kapcsolatot mutat a szülő iskolai végzettségével. Eredményeink alátámasztják a szülói minta szere pét is, hiszen a gyermek IKT-használatának mértéke összefügg a szüló eszközhasználatának mértékével.

Kulcsszavak: IKT, óvodáskorúak, szülők, képernyőidő, tartalomfogyasztás, szocioökonómiai státusz

\section{Bevezetés}

A gyermekkori tapasztalatszerzés egyik fő forrásává egyre inkább a technológia-gazdag környezet válik (Arnott, 2017). Európa-szerte folyamatosan nő a fiatalkorú internethasználók aránya, s a fiatalok internetezés sel töltött ideje (Livingstone, Haddon \& Gorzig, 2012), azonban a kilenc éven aluli gyermekek körében még markánsabban jelentkezik ez a két tendencia (Holloway, Green \& Livingstone, 2013). A polarizált viták az eszközök jótékony és káros hatásáról rendre tematizálják a szakmai párbeszédet, a tömegkommunikációt és a hétköznapi gondolkodást egyaránt. A technológiai evolúció újabb és újabb termékei mindig számos kérdést, kételyt vetnek fel, és gyakran megosztják a szakmát és a közvéleményt. Kell-e a kisgyermek kezébe ilyen eszköz? Jót tesz-e a szülő gyermekének, ha bekapcsol neki egy játékot az okostelefonon? Mi lehet az arany középút a digitális eszközhasználat tekintetében? Összefügg-e a szülői eszközhasználat mértéke a gyermek képernyő előtt töltött idejével? Vizsgálatunk ezúttal a szülók szemszögéből keres ezen a kérdések közül néhányra választ, egyrészről, hogy bővítse a kevés számú, a témában erről a korosztályról rendelkezésre álló adatok és szakirodalom körét, másrészről, hogy segítse a szülőket, az óvodapedagógusok munkáját, a csoportszobai tevékenységek tervezését.

\footnotetext{
* SZTE JGYPK API Óvodapedagógus-képző Tanszék, agihodi@jgypk.szte.hu

** MTA-SZTE Képességfejlődés Kutatócsoport, tothedit@edpsy.u-szeged.hu

*** SZTE BTK Neveléstudományi Intézet Pedagógiai Értékelés és Tervezés Tanszék, mary@edpsy.u-szeged.hu

**** SZTE JGYPK API Óvodapedagógus-képző Tanszék, dalice@jgypk.szte.hu
} 


\section{Elméleti háttér}

Tapasztaljuk, hogy az információs-kommunikációs technológiák mindennapjaink, s ennélfogva a gyermekek mindennapjainak is szerves részét képezik. Így, ha körülnézünk környezetünkben, azt látjuk, a legkisebbek is nagyon ügyesen használják már az okostelefont, a táblagépet stb. Holloway, Green és Livingstone (2013) rámutatnak arra, hogy a fejlettebb országokban a legtöbb kétéves kor alatti gyermek használ IKT-eszközöket, s jelen van az online térben. Tanulmányuk rávilágít arra, hogy a digitális eszközök térnyerésével párhuzamosan a 2000-es évektől kezdve - növekedett azon Európában végzett kutatások száma is, amelyek a háztartások IKT-felszereltségét, a gyermekek és fiatalkorúak internet-hozzáférését, internet-használatát és online viselkedését vizsgálják. A metaelemzés szerint a kutatások jelentős része a kamaszkorú gyerekkel foglalkozik, az 1200 elemzett tanulmányból 230 (19,2\%) vizsgál kilenc évnél fiatalabb gyermekeket. A legfiatalabbakra (0-4 éves) fókuszáló empirikus vizsgálatok száma még alacsonyabb, velük kapcsolatban csupán mintegy 50 munka járta körül a digitális témát valamilyen aspektusból (Holloway et al., 2013). A publikáció megjelenése óta hét év telt el, amely a digitális technológia fejlődése és terjedése szempontjából hatalmas időtartam. Ez idő alatt további nemzetközi vizsgálatokat végeztek, de az óvodáskorúak vonatkozásában tett megállapítások még mindig alulreprezentáltak.

A témában megjelenő magyar vonatkozású munkák száma szintén rendkívül elenyésző. Az Eu Kids Online folyamatosan frissülő adatbázisa szerint - bár a lista meglátásunk szerint korántsem teljes - a cikk megjelenésének idején 15 magyar vagy magyar vonatkozású tanulmányban értekeztek a gyermekek, illetve fiatalkorúak online tevékenységeiről, valamint annak lehetséges hatásairól, veszélyeiről. ${ }^{1}$ Jelen tanulmányban közölt kutatás szempontjából meghatározó vizsgálatot végzett a Nemzeti Média és Hírközlési Hatóság, melynek eredményei szintén alátámasztják azt, hogy már a legfiatalabb korosztály (3 éven aluliak) IKT-eszköz használatával, illetve tartalomfogyasztásával is számolnunk kell. Bár a nem reprezentatív vizsgálat szerint erre a korosztályra a televíziónézéshez képest kevésbé jellemző az internetezés, a szülők döntő többsége szerint nem szokta gyermeke az internetet használni. Akik azonban mégis, azok délutánonként használják azt, s kevesebb, mint fél órát. Hasonlóképpen alakulnak a hétvégi internetezési szokások is, de akkor minimálisan több időt töltenek a gyerekek internetezéssel a hétköznapokhoz képest. Zömében a gyerekek nem a szüleikkel használják a netet, amennyiben mégis, kevesebb, mint napi fél órát. A gyermekek leggyakrabban okostelefonon (38,5\%) keresztül interneteznek, ezt követi a táblagéppel (24,1\%), valamint számítógéppel (23,1\%) való csatlakozás a világhálóra (Nemzeti Média- és Hírközlési Hatóság [NMHH], 2018). A kisgyermekek körében különösen az érintőképernyős eszközök (pl. tablet és okostelefon) az elterjedtek (NMHH, 2018; Pintér, 2016), hiszen ezek használata egyszerúbb, nem igényel olyan kifinomult motoros képességeket, mint a számítógépek és a videojátékok (Konok, 2018). Ezekkel az eredményekkel összecsengenek Konok (2018) adatai is, aki a szülók nevelési stílusainak 0-7 éves korúak mobil képernyőérintős eszközök használatára gyakorolt hatására vonatkozóan végzett online kérdőíves felmérést a szülók körében. Eredményei szerint a válaszadó szülő́k gyermekeinek több mint egyharmada egy- és kétéves kora között kezdte el használni ezeket az eszközöket. Tanulmányából az is kiderül, hogy minél idősebb a gyermek, annál több időt tölt ezen eszközök használatával.

Számos jel utal tehát arra, hogy a gyermeknevelésben érintetteknek számolniuk kell az IKT-eszközök használatának, illetve a képernyőidőnek a hatásaival. A képernyőidő azt az időtartamot jelenti, amely alatt az egyén számítógépet, videojátékokat vagy kézi videójáték-konzolt, táblagépet vagy okostelefont használ, vagy TV-t,

1. http://www.Ise.ac.uk/media@Ise/research/EUKidsOnline/DB/home.aspx?

collection=eu_kids_online\&profile=_default\&form=simple_frag\&query=hungary\&start_rank=11 
DVD-t néz. A képernyőidő lehet (1) interaktív - például videojátékok játszása, kommunikáció Skype-on keresztül, vagy online eszközök használata rajzoláshoz, (2) nem interaktív - például filmek, TV-músorok vagy YouTube videók nézése. Más megközelítésben beszélhetünk (1) oktatási célú, valamint (2) szabadidős képernyőidőről.

A témát napirendre tűző gyermekgyógyászokat tömörítő szervezetek úgy látják, hogy szükséges korlátozni a gyermekek napi képernyőidejét. Javaslatukat azzal indokolják, hogy a valós, nem virtuális térben zajló interakciók pozitívabb hatást gyakorolnak a gyermekek fejlődésére és jólétére. Az Amerikai Gyermekgyógyászati Akadémia (AAP) legutóbbi, 2016-ban frissített képernyőidőre vonatkozó ajánlásai (Chassiakos, Radesky, Christakis, Moreno \& Cross, 2016):

- a 18 hónaposnál fiatalabb gyermekeknek kerülniük kellene a képernyőidőt, ez alól kivételt képez a vi deocsevegés,

- a 18 hónapos és 2 éves kor közötti gyermekek nézhetnek vagy használhatnak jó minőségú programokat vagy alkalmazásokat, abban az esetben, ha a felnőttek figyelemmel kísérik, illetve velük együtt tartalomfogyasztanak, hogy elmagyarázhassák gyermeküknek, mit látnak,

- a 2-5 éves gyermekek számára a képernyőn töltött idő nem lehet több, mint napi egy óra, de a felnőttel való közös tevékenykedés ebben az esetben is javasolt,

- a 6 éves és annál idősebb gyermekek számára javasolt következetes korlátozást bevezetni a képernyőidő és tartalomfogyasztás tekintetében egyaránt.

A Kanadai Gyermekgyógyászati Társaság 2017-ben hasonló irányelveket adott ki azzal a kiegészítéssel, hogy nem ajánlják az eszköz használatát lefekvés előtt egy órával (Canadian Paediatric Society Digital Health Task Force, 2017). Ezzel szemben az egyesült királyságbeli gyermekgyógyászokat és gyermekegészségügyi szakmai szervezet (Royal College of Paediatrics and Child Health) legújabb tájékoztató kiadványában (Viner, Davie \& Firth, 2019) amellett érvel, hogy a képernyőidő hatásmechanizmusa kontextusfüggő (mikor, ki, kivel és mire használja az eszközt), továbbá jelenleg nem áll elegendő megbízható adat rendelkezésre arról, hogy a kép ernyő előtt eltöltött idő hogyan befolyásolja a gyermekek fejlődését, így a lefekvés előtti egy óra képernyőmentes időn kívül nem tudnak a gyermekek képernyőidejére vonatkozó egyetemes, mindenkire és minden eszközre vonatkozó küszöbértékeket meghatározni, illetve ajánlani, de elismerik, hogy a képernyőidő korlátozása a család médiafogyasztás-tervezésének elengedhetetlen része lehet. A szerzők azt javasolják, hogy a szülők annak mentén határozzák meg, illetve beszéljék meg gyermekükkel a képernyőidőre vonatkozó szabályokat, hogy mik a gyermek igényei, hogyan és mire, milyen céllal használja az eszközt és hogy milyen mértékben szorítja az eszközhasználat gyakorisága és időtartama háttérbe a fizikai és szociális tevékenységeket, valamint a fiziológiás szükségleteket. A Magyar Gyermekorvosok Társasága ez idáig nem adott ki a képernyőidőre vonatkozó aján lást.

Tény, hogy a vonatkozó szakirodalmakat böngészve a képernyőidő, illetve IKT-eszköz használat kapcsán an nak pozitív és negatív hatást tulajdonító vélekedéseket, tanulmányokat, vizsgálati eredményeket egyaránt találunk (Woo, White \& Lai, 2016). Vannak, akik azon az állásponton vannak, hogy a gyors technológiai fejlődés által elérhető információs, kommunikációs és interaktív tanulási színterek tárháza új utakat nyit a gyermekek tudásszerzésében, tanulásában és felnőtté válásában (Arnott, 2017; Molnár, 2011; M. Pintér, 2016). Mások a digitális eszközök és az azokon keresztül elérhető ellenőrizetlen tartalmak miatti egyre nagyobb veszélyeztetettséget hangsúlyozzák (Magyarország Digitális Oktatási Stratégiája [MDOS], 2016, p. 141). De a képernyőidővel összefüggésbe hozott negatív hatások között szerepel a fizikai (pl. fájdalmas, irritált és száraz szem, fejfájás és fáradtság, SMS-nyak, elhízás az egyéb fizikai aktivitást igénylő tevékenységek elhanyagolása miatt), a fejlődési (befolyásolhatja az anyanyelvi és szociális fejlődést, figyelmet, testbeszéd olvasását), és biztonsági 
kockázat is (pl. nem gyermekbarát, veszélyes tartalmak, zaklatás). A képernyőidőnek lehetnek azonban előnyei is. A filmek, a videojátékok és az internet pozitív hatással lehet a gyermekre különösen akkor, ha a szülő részt vesz a tevékenységekben, segít gyermekének minőségi tartalmakat kiválasztásában vagy beszél gyermekével arról, hogy mi történik a játékban vagy a programban (Holloway et al., 2013). Viner, Davie \& Firth (2019) hangsúlyozza, hogy egy vizsgálat sem állapított meg ok-okozati összefüggést a képernyőidő és a fenti tényezők fennállása között. A kapcsolat irányának és erősségének tisztázása céljából mérföldkőnek és egyúttal világviszonylatban is úttörőnek/meghatározónak számít az amerikai Nemzeti Egészségügyi Intézet (National Institutes of Health [NIH]) több mint 11874 gyermek körében végzett hosszútávú, kilenc éves kortól fiatal fel nőttkorig tartó követéses vizsgálata, amelynek célja azon környezeti, szociális, genetikai vagy egyéb biológiai tényezők feltárása, amelyek befolyásolják az agyi és kognitív fejlődést és segíthetik vagy gátolhatják egy gyermek fejlődését. A kutatás arra is lehetőséget ad, hogy megismerjük, hogy a képernyő előtt eltöltött idő milyen hatást gyakorol az agy szerkezetére, a gyermekek érzelmi fejlődésére és mentális egészségükre (ABCD, 2019). Az első adatok azt sugallják, hogy már napi két óra képernyő előtt eltöltött idő is negatívan befolyásolhatja a gyermekek fejlődését. Azok a gyermekek, akik több mint napi két órát töltöttek a különböző eszközök használatával, alacsonyabb teljesítményt nyújtottak a gondolkodási és nyelvi képességeket vizsgáló teszteken.

A szülők szerepe megkérdőjelezhetetlen a képernyő kontrollálás és mintaadás tekintetében, mivel a kisgyermekek új technológiák széles skálájához férnek hozzá otthonukban (Antalóczy, Pörczi \& Vaskuti, 2012; Nikolopoulou, Gialamas \& Batsouta, 2010; Plowman, McPake \& Stephen, 2010). Az otthoni, családon belül megszerzett minta komoly hatással van a gyermekek fejlődésére, tudatosságára. A „3-7 éves korosztály közvetlen oktatása kevésbé hatékony, helyette a szülőkön, pedagógusokon keresztüli minta alapú viselkedésformálás vezethet eredményre" (MDOS, 2016, p. 141). Ennek érvényességét támasztja alá Konok (2018) munkája is. Tanulmányában elsőként mutat rá a digitális nevelési stílusok létezésére, valamint arra, hogy a szülők iskolai végzettsége, viselkedési mintája, a digitális nevelési stílusuk, a korai mobil érintőképernyős eszközök használatával kapcsolatos attitǔdjeik és vélekedéseik nagymértékben befolyásolják a gyermekek eszközhasználatát. Következésképpen a szülők felvilágosításán, digitáliseszköz-használati mintájának megváltoztatásán keresztül a gyermekek eszközhasználata hatékonyan formálható.

A KSH 2005 óta évenként frissülő adataiból arra következtethetünk, hogy az otthonok IKT-eszköz ellátottsága tekintetében a digitális szakadék a mobiltelefonok széleskörú elterjedésének köszönhetően minimálisra csökkent - arányuk a magyar háztartásokban 2013-ban 95,5\% (Fáyné Dombi, Hódi \& Kiss, 2016). Azonban az egyéb infokommunikációs eszközök (pl. számítógép: 53,2\%, laptop: 45,4\%) alacsonyabb aránya arra enged következtetni, hogy a magyar népesség körében még mindig nagy különbségek maradtak (KSH, 2014). A 2017-es adatok szerint a magyar lakosság közel 90\%-a csaknem napi rendszerességgel használja az internetet, az interneten heti és havi rendszerességgel böngészők aránya 10\% alatti (KSH, 2017).

A különböző társadalmi-gazdasági tényezők és a gyermekek jellemzői (kor és nem) összefüggésbe hozhatók a gyermekek otthoni IKT-hozzáférésével és -használatával (Rathbun, West \& Hausken, 2003; Calvert, Rideout, Woolard, Barr \& Strouse, 2005). Az Amerikai Egyesült Államokban 2014-ben az alacsony jövedelmú családok 83\%-a rendelkezett táblagéppel, 77\%-a okostelefonnal. Majdnem minden gyermek (97\%) használt mobileszközöket, és a legtöbb 4 éves gyermek rendelkezett saját mobileszközzel. Az 1400 0-8 éves korú gyermek szüleinek körében végzett tengerentúli reprezentatív mérés nem mutatott ki különbséget az alacsony és magas jövedelmú gyermekek számítógépes játékkal, oktatási szoftverrel, házi feladattal vagy más tevékenységgel töltött ideje között, bár jelentős hiányosságokat dokumentált az oktatási alkalmazások mobil eszközökön történő használatában (Bassok, Finch, Lee, Reardon \& Waldfogel, 2016). Harris, Straker és Pollock (2016) 6-17 éves 
ausztrál gyermekekre vonatkozó eredményei pedig arra mutatnak rá, hogy bár a hozzáférés tekintetében valóban nem mutatkozik digitális szakadék, a felhasználás, a képernyő előtt töltött idő minőségében szerepet játszik a család szocioökonómiai háttere.

Megjegyezzük, hogy egy négy európai országra (hazánkon kívül Törökország, Hollandia és Görögország) kiterjedő vizsgálat eredményei szerint nincsenek könnyű helyzetben a magyar kisgyermekes szülők a megfelelő, fejlesztő tartalmak kiválasztásában, mert alapvető probléma, hogy kevés a magyar nyelvű alkalmazás és a legtöbb elérhető applikáció inkább iskoláskorúak készségfejlesztésére való (Sari, Takács \& Bus, 2017).

\section{Kutatási kérdések}

Amint azt a nemzetközi kutatások mutatják, az óvodáskorú gyermekek jelentős aránya használja az okoseszközöket, de az eszközhasználat tendenciái és jellemzői országonként eltérő mintázatot mutatnak. A kamaszkorú fiatalok IKT-eszközhasználati és internetezési szokásairól, illetve ezek veszélyeiről tájékozódhatunk néhány hazai vizsgálat eredményéből (pl. Fazekas \& Cs. Czaczhesz, 2011; Dorner et al., 2016; Prievara \& Pikó, 2015; Tatai \& Kovács, 2016). Az óvodáskorú gyermekek IKT-eszközhasználatának jellemzőiről azonban nem állnak rendelkezésre nagymintás vizsgálatokból származó hazai adatok, s nem képezte kutatás tárgyát, hogy a gyermekek IKT-eszközhasználati szokásait hogyan befolyásolják szüleik IKT-eszközhasználati szokásai, s kontrollja. Tanulmányunkban e témaköröket elemezzük, s az alábbi konkrét kutatási kérdésekre keressük a választ:

- Milyen IKT-eszközök és mekkora számban találhatók a gyermekek otthonában?

- Milyen gyakran használják a gyermekek ezeket az eszközöket otthon?

- Mennyi időt töltenek a gyermekek a képernyő előtt?

- Milyen tartalmakat fogyasztanak a gyermekek?

- Hogyan kontrollálják a szülők gyermekeik IKT-eszközhasználatát?

- Hogyan befolyásolja a szülők iskolázottsága gyermekeik IKT-eszközhasználatát?

\section{Módszerek}

\section{Minta}

A mintavételezés során kutatásunk feltáró jellegéből indultunk ki, így elsősorban arra törekedtünk, hogy vizsgálati mintánk tartalmazza a kutatásunk szempontjából fontos jegyeket, tehát olyan családok körét, (1) amelyben megtalálható a szociokulturális háttér széles spektruma, illetve (2) családszerkezeti jellemzők alapján jól differenciálható. Ezeknek a feltételnek eleget teszünk, ha egy megyei jogú város minden önkormányzati intézményét bevonjuk kutatásunkba. Vizsgálatunkban összesen 3969 kérdőívet osztottunk ki egy megyeszékhely 43 önkormányzati fenntartású óvodájában a gyermekek szülei/nevelőszülei részére. A beérkezett és feldolgozott kérdóívek száma 1881, tehát a teljes minta - a vizsgált populáció - 47,4\%-áról kaptunk adatokat. Kutatásunkban a „Melyik csoportba jár gyermeke?” kérdésre adott válaszok alapján részmintákat hoztunk létre. A kapott csoportokban az átlagéletkor és a legfiatalabb, illetve legidősebb tanuló életkora megfelel az életkori sávok szerinti óvodai csoportokénak. Így, bár a vizsgált intézményekben változó a gyermekcsoportok életkor szerinti összetétele (sávos vagy ún. vegyes), nem követünk el hibát, ha az elemzésünkben kis- és középső csoportbontást használunk. Adataink szerint (2. táblázat) a kitöltött kérdőívek aránya közel azonos a kis- és közép ső csoportban, legtöbben a nagycsoportos gyermekek szülei válaszoltak a kérdésekre. Ugyanakkor a nagycsoportos korúak száma a legnagyobb az intézmények összességében is. A kérdőívek 30,4\%-át kiscsoportos, 
30,3\%-át középső csoportos és 38,4\%-át nagycsoportos korú gyermekek szülei töltötték ki (1. táblázat). A nagycsoportosok magasabb arányát magyarázza, hogy az évvesztes, valamint a nem iskolaérett gyerekek jellemzően a nagycsoportban töltik a negyedik óvodai évüket.

A fiúk és lányok közel azonos arányban vannak jelen a mintában. A feldolgozott válaszokban a gyermekek nemek szerinti aránya közel azonos (fiúk aránya: 51,4\%). A kérdőívek 85,5\%-át az anyák töltötték ki, az arány hasonló az egyes ( $N_{\text {kis }}=575, N_{\text {középsó }}=567, N_{\text {nagy }}=723$ ) csoportokban. A válaszadók átlagéletkora 37,1 év (minimum 20 év, maximum 60 év szórás: 5,3 év). A válaszadók többsége, közel 75,0\%-a, 40 év alatti.

\begin{tabular}{|lr|rrr|}
\hline \multicolumn{1}{|c|}{ Változók } & Kiscsoport & $\begin{array}{c}\text { Középső } \\
\text { csoport }\end{array}$ & Nagycsoport & Teljes minta \\
\hline Gyermekek száma (aránya) & $575(30,4 \%)$ & $567(30,3 \%)$ & $723(38,4 \%)$ & $1881(100 \%)$ \\
\hline Gyermekek átlagéletkora (év) & 3,5 & 4,7 & 6,0 \\
\hline Fiúk aránya (\%) & 53,2 & 49,8 & 50,8 & 51,4 \\
\hline
\end{tabular}

Megjegyzés: 16 szülő nem adta meg, milyen csoportos korú a gyermeke.

A válaszadó szülők 2,8\%-a legfeljebb általános iskolai végzettséggel rendelkezik, 8,9\%-a szakiskolát végzett, egyharmada érettségizett (33,7\%), több mint fele (54,7\%-a) felsőfokú végzettségú (2. táblázat).

\begin{tabular}{|c|c|c|c|c|c|c|c|c|}
\hline \multirow{2}{*}{ Iskolai végzettség } & \multicolumn{2}{|c|}{$\begin{array}{l}\text { Kiscsoport } \\
(\mathrm{N}=572)\end{array}$} & \multicolumn{2}{|c|}{$\begin{array}{l}\text { Középső csoport } \\
\qquad(\mathbf{N}=567)\end{array}$} & \multicolumn{2}{|c|}{$\begin{array}{l}\text { Nagycsoport } \\
\quad(\mathbf{N}=720)\end{array}$} & \multicolumn{2}{|c|}{$\begin{array}{l}\text { Teljes minta } \\
\qquad(\mathbf{N}=\mathbf{1 8 7 5})\end{array}$} \\
\hline & $\mathbf{N}$ & $\%$ & $\mathbf{N}$ & $\%$ & $\mathbf{N}$ & $\%$ & $\mathbf{N}$ & $\%$ \\
\hline Általános iskola & 19 & 3,3 & 18 & 3,2 & 13 & 1,8 & 52 & 2,8 \\
\hline $\begin{array}{l}\text { Szakiskola, } \\
\text { szakmunkásképző }\end{array}$ & 55 & 9,6 & 49 & 8,6 & 61 & 8,5 & 166 & 8,9 \\
\hline Szakközépiskola & 87 & 15,1 & 81 & 14,3 & 135 & 18,8 & 305 & 16,3 \\
\hline Gimnázium & 53 & 9,2 & 58 & 10,2 & 69 & 9,6 & 182 & 9,7 \\
\hline Technikum & 42 & 7,3 & 48 & 8,5 & 52 & 7,2 & 144 & 7,7 \\
\hline Főiskola (BA, BSc) & 181 & 31,5 & 180 & 31,7 & 214 & 29,7 & 578 & 30,8 \\
\hline $\begin{array}{l}\text { Egyetem (MA, } \\
\text { MSc) }\end{array}$ & 117 & 20,3 & 117 & 20,6 & 152 & 21,1 & 390 & 20,8 \\
\hline $\begin{array}{l}\text { Doktori fokozat } \\
\text { (PhD) }\end{array}$ & 18 & 3,1 & 16 & 2,8 & 24 & 3,3 & 58 & 3,1 \\
\hline
\end{tabular}

2. táblázat. A válaszadó szülők iskolai végzettség szerinti megoszlása 


\section{Mérőeszköz}

A kutatási kérdések vizsgálatát saját fejlesztésú kérdőívvel végeztük. A kérdőív összeállításakor különböző életkorú gyermekek IKT-eszközhasználati szokását vizsgáló hazai és külföldi mérőeszközökre is támaszkodtunk (lásd Nikolopoulou et al., 2010; NMHH, 2018). A négy tematikus egységből álló kérdőív 65, a szülőre és gyermekére vonatkozó tételből áll, melyek közül hét nyílt végú. Az első két rész a demográfiai adatokról (pl. életkor, nem, gyermekek száma, szülő iskolai végzettsége), a háztartásban lévő IKT-eszközök fajtáiról és számáról, használatuk gyakoriságáról és időtartamáról, valamint a használat céljáról (mire használják az adott eszközt) gyűjt információt a szülőre és a gyermekére vonatkozóan. A harmadik egységben a szülő óvodáskorban és óvodában történő eszközhasználattal kapcsolatos ismereteit és véleményét feltáró kérdések szerepelnek, míg a negyedik részt alkotó tételek a gyermek eszközhasználatával, tartalomfogyasztásával kapcsolatos szokásaira, és a szülő kontrolláló tevékenységeire, az eszközhasználat, tartalomfogyasztás alatti szülő-gyermek interakció jellemzőire, annak gyakoriságára vonatkoznak.

\section{Adatgyüjtés}

Az adatfelvétel az intézmények vezetőinek előzetes jóváhagyásával, az intézmények meghatalmazott képviselőjének (jellemzően az óvónők) közreműködésével történt. Az óvodák az oda járó gyermekek számával azonos számú kérdőívet kaptak. A kérdőív papír alapú volt, mert elsődleges célunk a teljes körú hozzáférés biztosítása volt, másodsorban nem vártunk el a szülőktôl jártasságot az online kérdőívek kitöltésében. Az anonim adatfelvételt az óvodák szervezték a helyi gyakorlatnak és a szülőkkel való kapcsolattartás kialakult szokásainak megfelelően. A kérdőív kitöltése hozzávetőlegesen 20 percet vett igénybe, a válaszadás önkéntes volt.

\section{Eredmények}

\section{Az óvodáskorú gyermekek IKT-eszközei}

A feldolgozott kérdőívek adatai szerint a gyerekek 68,3\%-ának (1285 fö) nincs saját IKT eszköze (3. táblázat). Az óvodáskorú gyermekeknek jellemzően (395 fő, a teljes minta 21,0\%-a) táblagépe van. A gyermekek 9,1\%-a (171 fő) rendelkezik okostelefonnal, 2,0\%-a (38 fö) számítógéppel vagy laptoppal. Eredményeink szerint a nagycsoportos gyermekek nagyobb arányban rendelkeznek saját IKT-eszközzel, mint fiatalabb társaik $\left(F_{\text {szgép/laptop }}=3,093, p<0,046 ; F_{\text {táblagép }}=13,908, p<0,001, F_{\text {okostelefon }}=9,071, p<0,001 ; F_{\text {nincs }}=24,725, p<0,001\right)$. 


\begin{tabular}{|c|c|c|c|c|c|c|c|c|}
\hline \multirow{2}{*}{ A gyermeknek... } & \multicolumn{2}{|c|}{$\begin{array}{l}\text { Kiscsoport } \\
(\mathrm{N}=\mathbf{5 7 2})\end{array}$} & \multicolumn{2}{|c|}{$\begin{array}{l}\text { Középső } \\
\text { csoport } \\
(\mathbf{N}=567)\end{array}$} & \multicolumn{2}{|c|}{$\begin{array}{l}\text { Nagycsoport } \\
\qquad(\mathbf{N}=720)\end{array}$} & \multicolumn{2}{|c|}{$\begin{array}{l}\text { Teljes minta } \\
\qquad(\mathbf{N}=\mathbf{1 8 7 5})\end{array}$} \\
\hline & $\mathbf{N}$ & $\%$ & $\mathbf{N}$ & $\%$ & $\mathbf{N}$ & $\%$ & $\mathbf{N}$ & $\%$ \\
\hline ...van számítógépe / laptopja. & 7 & 1,2 & 9 & 1,6 & 22 & 3,0 & 38 & 2,0 \\
\hline ...van táblagépe. & 82 & 14,3 & 120 & 21,2 & 190 & 26,3 & 395 & 21,0 \\
\hline ...van okostelefonja. & 33 & 5,7 & 45 & 7,9 & 89 & 12,3 & 171 & 9,1 \\
\hline ...nincs saját IKT-eszköze. & 447 & 77,7 & 396 & 69,8 & 434 & 60,0 & 1285 & 68,3 \\
\hline
\end{tabular}

3. táblázat. A gyermekek saját IKT eszközeinek száma és aránya (\%)

\section{A gyermekek eszközhasználatának heti gyakorisága}

Vizsgálatunk alapján a kiscsoportos gyermekek 76,2\%-a (438 fő) használ valamilyen IKT- eszközt. A középső csoportban ez az arány 83,4\% (473 fö), a nagycsoportban 86,4\% (625 fö). A leginkább használt eszköz mindhárom korcsoportban az okostelefon. A gyerekek közel 57,0\%-a egyáltalán nem, közel 10\%-uk pedig napi szinten használ számítógépet, laptopot (1. ábra). Legkevésbé a kiscsoportos korú gyerekekre jellemző a számítógépezés, a középső és nagycsoportosok körében inkább jelen van a számítógép-használat, a válaszok e két csoportban hasonló mintázatot mutatnak $(F=4,23, p<0,015)$. Táblagépet a vizsgált gyerekek fele egyáltalán nem használ, a kiscsoportban ez az arány 62\%, a két nagyobb csoportban a táblagépet nem használók köre jelentősen alacsonyabb. A használat gyakoriságában a középső és a nagycsoportban hasonló tendenciák figyelhetők meg (2. ábra; $F=11,61, p<0,001)$. Leginkább az okostelefont használják a gyerekek minden korcsoportban, az okos telefont egyáltalán nem használók aránya 46\% (3. ábra). Az okostelefon használatának gyakoriságára vonatkozóan mindhárom csoportban hasonló mintázat figyelhető meg. Ez esetben a kiscsoportos korúakra vonatkozó válaszok nem különülnek el a másik két csoporttól ( $F=1,29, p<0,275)$.

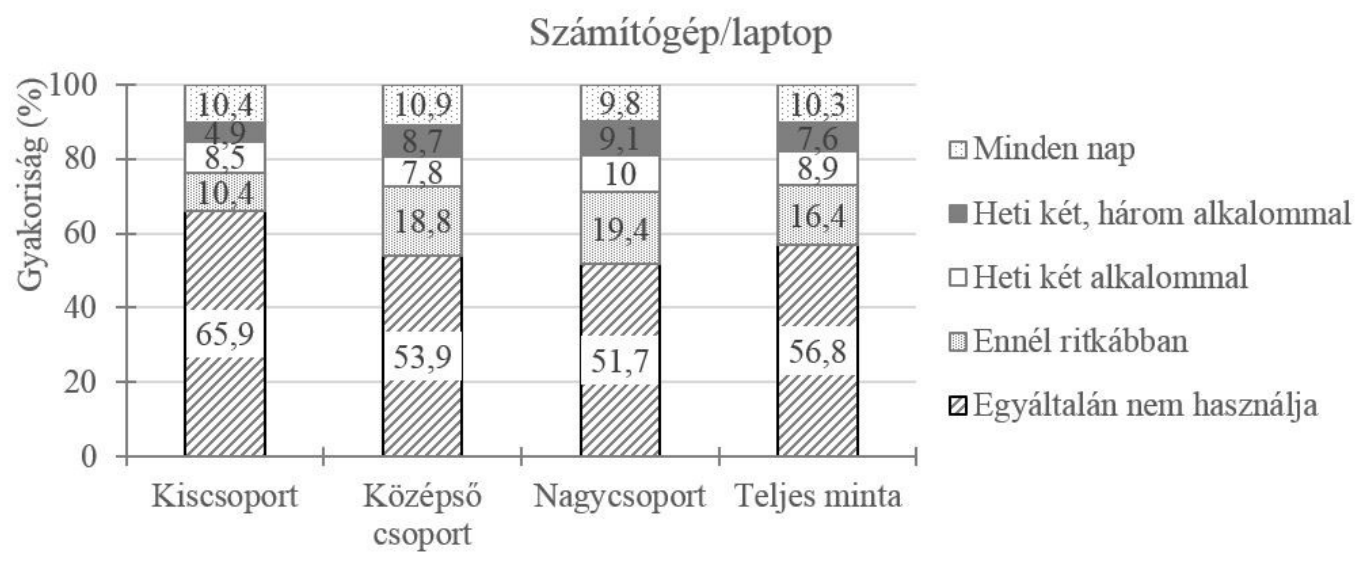

1. ábra. A gyermekek számítógép/laptop-használatának gyakorisága (\%). 
Tablet

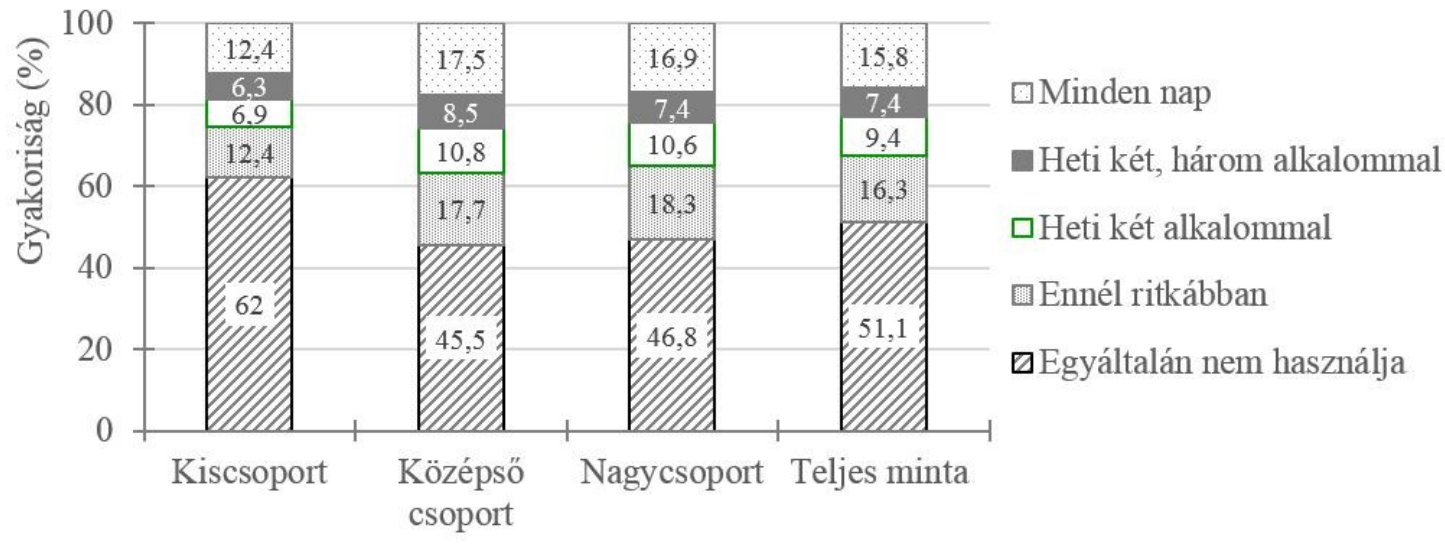

2. ábra. A gyermekek táblagép-használatának gyakorisága (\%).

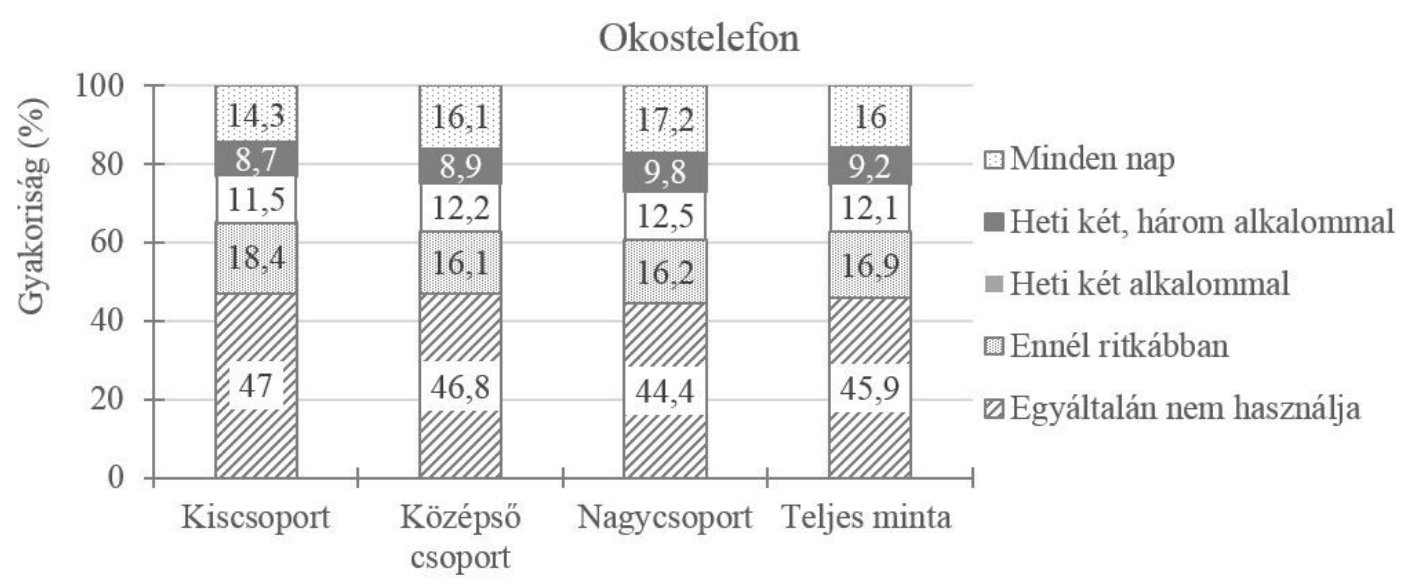

3. ábra. A gyermekek okostelefon-használatának gyakorisága (\%).

\section{A gyermekek otthoni IKT-eszközhasználatának heti idótartama}

Eredményeink szerint azok a gyermekek, akik használhatnak számítógépet és/vagy laptopot, hetente átlagosan 3,3 órát töltenek a gép előtt, akik használhatnak táblagépet, azok közel 4 órát, akik pedig okostelefont, azok átlagosan heti 3 órát használják azt (4. táblázat). Annak ellenére, hogy legtöbben az okostelefont használják, a legkevesebb időt ezzel az eszközzel foglalatoskodnak. Az eszközhasználat időtartamában nincs különbség a három csoport között ( $F_{\text {szgép/laptop }}=1,02 F_{\text {táblagép }}=1,55 F_{\text {okostelefon }}=2,52$ p0,05). 


\begin{tabular}{|lcccccc}
\hline & \multicolumn{2}{c}{ Számítógép / laptop } & \multicolumn{2}{c}{ Táblagép } & \multicolumn{2}{c}{ Okostelefon } \\
\hline Részminták & $\mathbf{N}$ & $\begin{array}{c}\text { óra } \\
\text { (szórás) }\end{array}$ & $\mathbf{N}$ & $\begin{array}{c}\text { óra } \\
\text { (szórás) }\end{array}$ & N & óra (szórás) \\
\hline Kiscsoport & 166 & $3,3(3,2)$ & 184 & $3,8(3,6)$ & 260 & $2,7(2,9)$ \\
\hline Középső csoport & 207 & $3,1(2,7)$ & 247 & $3,8(3,4)$, & 259 & $2,8(2,9)$ \\
\hline Nagycsoport & 292 & $3,4(3,6)$ & 321 & $4,1(3,9)$ & 335 & $3,2(3,3)$ \\
\hline Teljes minta & 671 & $3,3(3,2)$ & 758 & $3,9(3,7)$ & 863 & $2,9(3,1)$ \\
\hline
\end{tabular}

Azok a gyermekek, akikről szüleik azt nyilatkozták, hogy használnak IKT-eszközöket, hetente átlagosan 5,1 órát használják azt. Az adatok szerint minél idősebb a gyermek, annál több időt tölt IKT-eszközökkel egy héten: a kiscsoportos eszközhasználó gyermekek hetente átlagosan 4,4 órát, a középsősök 5,0 órát, míg a nagycsoportos gyermekek 5,5 órát (screen time), ( $F=5,32, p<0,01)$. A gyermekek IKT-eszközzel töltött ideje nem különbözik a szülők iskolai végzettségének függvényében.

\section{A gyermekek az IKT-eszközökön végzett tevékenységei, tartalomfogyasztási szokásai}

A válaszok alapján a legtöbb gyermek (80,1\%) meséket, filmeket néz a mobil eszközökön, illetve számítógépen, 38,4\%-uk fotó és képnézegetésre, 36,2\%-uk zenehallgatásra használja azokat. Az óvodás korosztályban nem jellemző a videójátékozás (6,5\%) illetve az, hogy a gyermekek kapcsolattartásra (8,1\%) céljából használják a vizsgált eszközöket. Eredményeink szerint a gyermek életkorával nő az általuk használt internetes források száma, újabb és újabb játékok világa nyílik meg előttük (5. táblázat). A $\chi^{2}$ próba alapján elmondhatjuk, hogy az életkorral növekszik (p0,01) azok köre, akik játszanak online vagy videojátékokkal, mobil játék-applikációkkal, s a színezés, rajzolás, zenehallgatás is jellemzőbb az idősebbek körében. Korcsoporttól függetlennek mutatkozik a mesenézés, a kapcsolattartás és a képnézegetés (p0,05). A szülők további, általunk fel nem sorolt aktivitásokat is megadhattak. Azokat áttekintve láthatjuk, hogy a gyerekek között van, aki az IKT-eszközöket például fotó készítésére, „olvasástanulásra”, „számképtanulásra” használja. 


\begin{tabular}{|c|c|c|c|c|c|c|c|c|}
\hline $\begin{array}{l}\text { Mire használja gyermeke az } \\
\text { IKT-eszközöket }\end{array}$ & \multicolumn{2}{|c|}{$\begin{array}{l}\text { Kiscsoport } \\
(\mathbf{N}=575)\end{array}$} & \multicolumn{2}{|c|}{$\begin{array}{c}\text { Középső } \\
\text { csoport } \\
(\mathbf{N}=567)\end{array}$} & \multicolumn{2}{|c|}{$\begin{array}{l}\text { Nagycsoport } \\
\qquad(\mathbf{N}=723)\end{array}$} & \multicolumn{2}{|c|}{$\begin{array}{l}\text { Teljes minta } \\
\qquad(\mathrm{N}=\mathbf{1 8 8 1})\end{array}$} \\
\hline Játszik online játékokkal & 38 & $(6,6)$ & 92 & $(16,2)$ & 173 & $(23,9)$ & 306 & $(16,3)$ \\
\hline Játszik videojátékokkal & 10 & $(1,7)$ & 37 & $(6,5)$ & 74 & $(10,2)$ & 122 & $(6,5)$ \\
\hline $\begin{array}{l}\text { Játszik mobil játék- } \\
\text { applikációkkal }\end{array}$ & 94 & $(16,3)$ & 168 & $(29,6)$ & 232 & $(32,1)$ & 498 & $(26,5)$ \\
\hline Kapcsolatot tart & 46 & $(8,0)$ & 50 & $(8,8)$ & 56 & $(7,7)$ & 153 & $(8,1)$ \\
\hline Színez, rajzol, fest & 104 & $(18,1)$ & 161 & $(28,4)$ & 237 & $(32,8)$ & 506 & $(26,9)$ \\
\hline $\begin{array}{l}\text { Meséket, filmeket, videókat } \\
\text { néz }\end{array}$ & 451 & $(78,4)$ & 461 & $(81,3)$ & 5801 & $80,3)$ & 1506 & $(80,1)$ \\
\hline Képeket, fotókat nézeget & 228 & $(39,7)$ & 233 & $(41,1)$ & 254 & $(35,1)$ & 722 & $(38,4)$ \\
\hline Zenét hallgat & 174 & $(30,3)$ & 198 & $(34,9)$ & 301 & $(41,6)$ & 681 & $(36,2)$ \\
\hline
\end{tabular}

A válaszok azt mutatják, hogy valamennyi, a vizsgálatban részt vett családban van legalább egy a felsorolt IKT-eszközök (számítógép/laptop, tablet, okostelefon) közül. Az eszközök háztartásokon belüli számát vizsgálva látható (4. ábra), hogy a számítógépből/laptopból a családok felében egy van, (937, 50,9\%) harmadában kettő (496, 32,4\%) okostelefonból jellemzően kettő (954, 51,3\%), illetve három (394, 21,2\%) van. Nincs táblagép 651 (36,1\%) háztartásban, míg a válaszadók 45,3\%-nak (817) otthonában megtalálható egy ilyen eszköz. A szülók több mint fele $(1088,61,1 \%)$ nyilatkozott úgy, hogy háztartásukban mindhárom eszköz fellelhető.

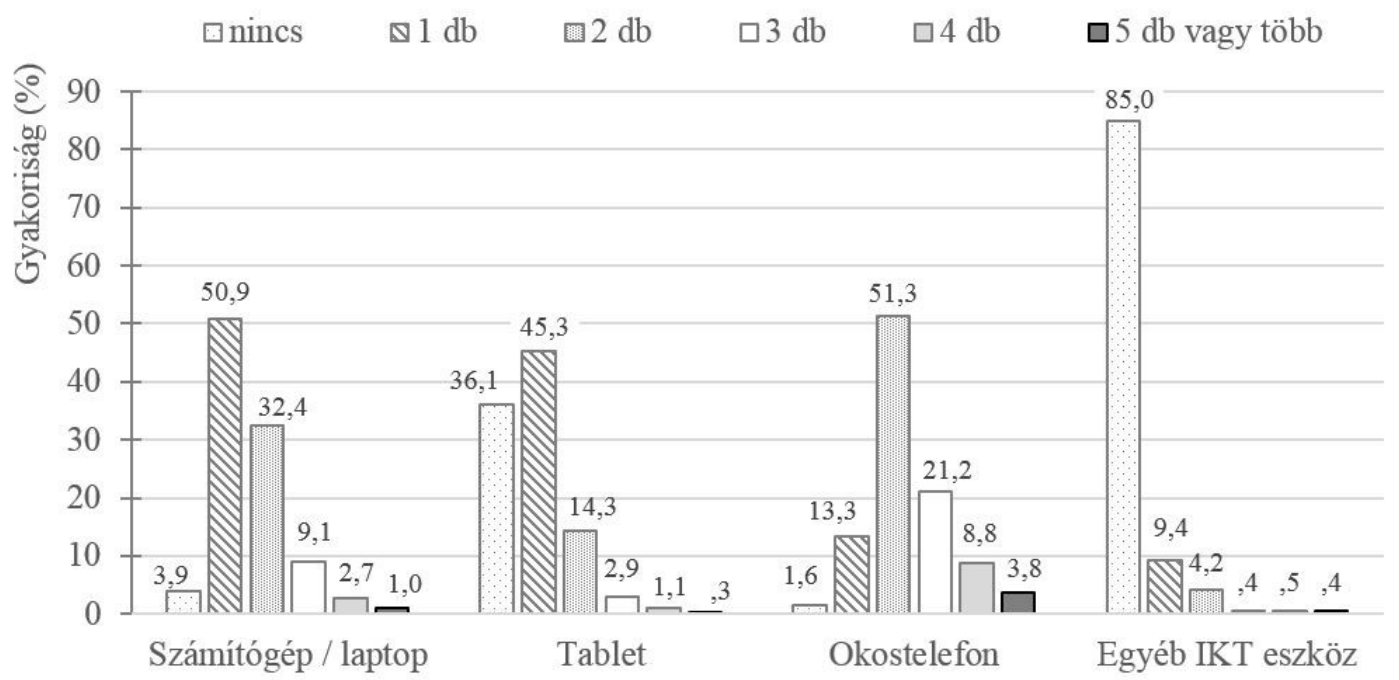

4. ábra. Az IKT-eszközök aránya a háztartásokban. 


\section{A szülők IKT-eszközhasználatának heti gyakorisága és időtartama}

Azon válaszadók, akik rendelkeznek számítógéppel vagy laptoppal, 51,4\%-a használják azt otthon napi rendszerességgel. Ugyanez az arány a táblagép esetében 23,3\% és az okostelefon esetében 98,3\%. Elemzésünk megmutatta, hogy a kérdőívet kitöltő szülők egy héten a leg-több időt az okostelefon (átlagosan 8,5 óra), a legkevesebbet a táblagép (4,2 óra) használatával töltik (6. táblázat).

\begin{tabular}{|c|c|c|c|}
\hline IKT eszköz & $\mathbf{N}$ & Átlag (óra) & Szórás (óra) \\
\hline Számítógép / laptop & 1449 & 7,1 & 10,1 \\
\hline Tablet & 459 & 4,2 & 7,0 \\
\hline Okostelefon & 1703 & 8,5 & 10,9 \\
\hline
\end{tabular}

6. táblázat. A válaszadó szülők otthoni IKT eszközhasználatának átlagos időtartama egy héten

A válaszok alapján a gyermekek különböző IKT-eszközzel töltött ideje között 0,3 feletti a korreláció, amely arról tanúskodik, hogy biztos kapcsolat van az egyes IKT-eszközökkel eltöltött időtartamok között (7. táblázat). Relatíve szorosnak mondható a kapcsolat $(r=0,456)$ a szülő okostelefonnal töltött ideje és a gyermek számítógépezésének heti időtartama között, de relatíve meghatározó $(0,301)$ a szülő és a gyermek számítógéppel töltött ideje közötti kapcsolat is.

\begin{tabular}{|c|c|c|c|c|}
\hline & \multirow{2}{*}{ Változók } & \multicolumn{3}{|c|}{ Gyermek } \\
\hline & & Számítógép/laptop & Táblagép & Okostelefon \\
\hline \multirow{2}{*}{ Gyermek } & Táblagép & 0,375 & 1 & \\
\hline & Okostelefon & 0,328 & 0,328 & 1 \\
\hline \multirow{2}{*}{ Szülő } & Számítógép/laptop & 0,301 & 0,134 & n.s. \\
\hline & Táblagép & 0,228 & 0,211 & 0,150 \\
\hline
\end{tabular}

7. táblázat. Összefüggés a gyermek és a válaszadó szülő IKT-eszközök használatának heti átlagos időtartama között. Megjegyzés: $n$. .s. : nem szignifikáns p<0,001

\section{A gyermekek IKT-eszközhasználatának kontrollálása}

Adataink szerint a szülők jelentős aránya tudatos eszközhasználó és odafigyel arra, gyermeke hogyan, mire használja az IKT-eszközöket (5. ábra). Eredményeink minden válasz esetében azon szülők körére érvényesek, akik azt nyilatkozták, gyermekük használhat IKT-eszközt. A szülők 60\%-a szinte mindig, 20\%-a gyakran választja ki, hogy gyermeke melyik programot használhatja, csupán a válaszadók 3,7\%-a nem teszi ezt. A szülők közel azonos aránya ismeri szinte mindig vagy gyakran a programokat, mielőtt megengedi annak használatát. A szülőknek csupán 6\%-a nem ellenőrzi, nem kíséri figyelemmel gyakran, vagy szinte minden esetben, hogy gyermeke mire használja az IKT-eszközt. A szülök ötöde gyermekével közösen használja az IKT-eszközöket szinte min dig, gyakran, van gyermeke mellett a szülők 33\%-a.

A hirdetéseket és a nem gyermekbarát weboldalakat a szülők negyede $(25,5 \%, 25,2 \%)$ egyáltalán nem tiltja le, több mint egyharmada, ill. fele pedig mindig megteszi ezt (32,2\%, 50,8\%). Jellemzően megszabják, hogy 
gyermekeik mennyi időt használhatják az IKT-eszközöket. Közel 60\%-uk mindig, 22\%-uk gyakran korlátozza az IKT-eszközökkel való foglalatoskodásra fordított időt, s csak 5,7\%-uk nem foglalkozik egyáltalán ezzel. A szülők több mint fele $(53,2 \%)$ válaszolta azt, hogy nem használja az IKT-eszközöket jutalmazásra, 11,5\%-uk nyilatkozta azt, hogy szinte mindig vagy gyakran az a jutalmazás eszköze. Mint büntetést többen alkalmazzák az IKTeszköz megvonását, 17,4\% szinte mindig, vagy gyakran, és $37 \%$ vallotta azt, hogy soha nem bünteti gyermekét azzal, hogy nem engedi az efféle időtöltést. A szülők fele (50,8\%) hívja fel gyermeke figyelmét rendszeresen (szinte mindig vagy gyakran) az IKT-eszközök használatának veszélyeire, másik felére ez nem igazán jellemző.

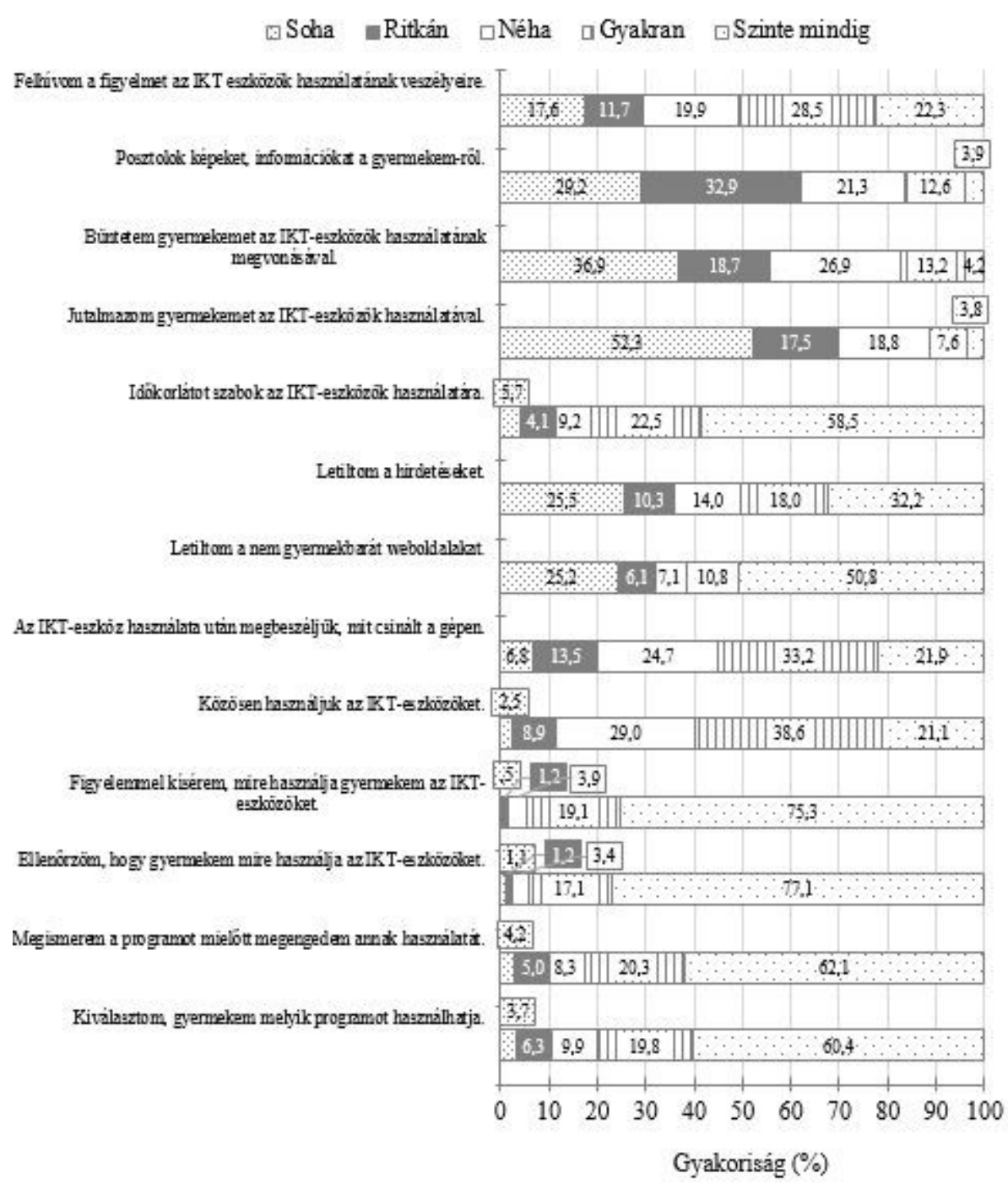

5. ábra. A „Milyen gyakran teszi Ön?” kérdésre adott válaszok gyakorisága (\%).

Megvizsgáltuk, mutatnak-e különbséget a válaszok a szülők iskolai végzettsége szerint. Elemzésünk alapján három vonatkozásban nem jelenik meg különbség, tehát iskolázottságtól független (1) a közös IKT-eszköz használat gyakorisága, (2) az IKT-eszköz használata utáni beszélgetés a tevékenykedésről, illetve (3) párbeszéd az online lét, az IKT-eszközök használatának veszélyeiről (8. táblázat). A többi esetben az iskolai végzettség mentén találtunk különbséget a válaszokban. Az általános iskolát végzett szülőkre kevésbé jellemző, mint a magasabb végzettségú szülókre, hogy kiválasztják, melyik programot használhatja gyermekük, hogy megismerik a használt programokat, hogy ellenőrzik, mire használja gyermekük az IKT-eszközöket, illetve figyelemmel 
kísérik az eszközökkel való foglalatoskodásaikat. A nem gyermekbarát weboldalak letiltása inkább a legfeljebb szak- vagy szakközépiskolát, általános iskolát végzettekre jellemző, kevésbé a magasabb iskolázottságúakra. Legkevésbé a felsőfokú végzettségű, illetve érettségizett szülők büntetik gyermekeiket az IKT-eszközök használatának megvonásával. Minél iskolázottabb a szülő, annál ritkábban oszt meg információkat, posztol képeket gyermekéről a különböző közösségi oldalakon, blogokon.

\begin{tabular}{|c|c|c|}
\hline Tételek & $\mathbf{F}$ & $\begin{array}{l}\text { Különbséget } \\
\text { mutató csoportok }\end{array}$ \\
\hline Kiválasztom, gyermekem melyik programot használhatja. & 11,57 & $1<2,3,4,5<6,7,8$ \\
\hline $\begin{array}{l}\text { Megismerem a programot mielőtt megengedem annak } \\
\text { használatát. }\end{array}$ & 6,16 & $1<2,3,4,5,6,7,8$ \\
\hline Ellenőrzöm, hogy gyermekem mire használja az IKT-eszközöket. & 6,39 & $1<2,3,4,5,6,7,8$ \\
\hline $\begin{array}{l}\text { Figyelemmel kísérem, mire használja gyermekem az IKT- } \\
\text { eszközöket. }\end{array}$ & 8,29 & $1<2,3,4,5,6,7,8$ \\
\hline Közösen használjuk az IKT-eszközöket. & n.s. & -- \\
\hline $\begin{array}{l}\text { Az IKT-eszköz használata után megbeszéljük, mit csinált a } \\
\text { gépen. }\end{array}$ & n.s. & -- \\
\hline Letiltom a nem gyermekbarát weboldalakat. & 5,06 & $8,7,4,6,5<2,1,3$ \\
\hline Letiltom a hirdetéseket. & 2,65 & $8<3$ \\
\hline Időkorlátot szabok az IKT-eszközök használatára. & 4,70 & $1<3,6,7$ \\
\hline Jutalmazom gyermekemet az IKT-eszközök használatával. & 4,65 & $8,4,7,6<2$ \\
\hline $\begin{array}{l}\text { Büntetem gyermekemet az IKT-eszközök használatának } \\
\text { megvonásával. }\end{array}$ & 8,45 & $8,7,4,6<1,3<5<2$ \\
\hline Posztolok képeket, információkat a gyermekemről. & 13,6 & $8,7<7,6<6,5,4,3,2<2,1$ \\
\hline $\begin{array}{l}\text { Felhívom a figyelmet az IKT eszközök használatának, és az } \\
\text { online jelenlétnek a veszélyeire. }\end{array}$ & n.s. & -- \\
\hline
\end{tabular}

\section{A szülő tevékenysége miközben gyermeke valamilyen IKT-eszközzel foglalja el magát}

A szülők 13,0\%-a nyilatkozott úgy, hogy gyermeke nem használ IKT-eszközöket, a legtöbb nemleges válasz a kiscsoportba járó gyermekekre vonatkozott (17,6\%), a másik két csoportba járó gyermekek vonatkozásában a gyakoriság közel azonos (11,8\%, 10,1\%). A válaszokból kitúnik, hogy a szülők leggyakrabban valamilyen munkát végeznek miközben a gyermekük IKT-eszközzel foglalja el magát (9. táblázat). A szülők mindhárom csoportban leggyakrabban házimunkát végeznek (57,3\%, 67,8\%, 69,5\%), illetve kisebb arányban dolgoznak (17,8\%, 23,2\%, 24,7\%). Az egyéni szabadidős tevékenységek gyakorisága hasonló, de kevésbé jellemző. A kiscsoport- 
ban valamennyi megkérdezett tevékenység végzésének gyakorisága alacsonyabb, mint a másik kettőben. Az egyéb tevékenységként többen az utazást adták meg, illetve többen számoltak be arról, hogy az indulás előtti készülődés is olyan időszak, amikor a gyermekeknek IKT-eszközöket adnak. A válaszok között azonban szerepelt olyan is, hogy a gyermek étkezés közben („őt etetem”) használ IKT-eszközt, vagy amikor a szülő a kisebb testvérrel foglalkozik, illetve a szülő maga is ott van gyermekével, együtt használják az IKT-eszközt.

\begin{tabular}{|c|c|c|c|c|}
\hline $\begin{array}{l}\text { Mit szokott leggyakrabban csinálni } \\
\text { ön, } \\
\text { miközben gyermeke valamilyen IKT- } \\
\text { eszközzel foglalja el magát? }\end{array}$ & $\begin{array}{l}\text { Kiscsoport } \\
(\mathbf{N}=557)\end{array}$ & $\begin{array}{c}\text { Középső } \\
\text { csoport } \\
(\mathrm{N}=543)\end{array}$ & $\begin{array}{l}\text { Nagycsoport } \\
\quad(\mathbf{N}=625)\end{array}$ & $\begin{array}{c}\text { Teljes } \\
\text { minta } \\
(\mathbf{N}=\mathbf{1 7 2 5})\end{array}$ \\
\hline $\begin{array}{l}\text { Nem használ a gyermekem IKT- } \\
\text { eszközt. }\end{array}$ & 17,6 & 11,8 & 10,1 & 13 \\
\hline Házimunkát végzek. & 57,3 & 67,8 & 69,5 & 65,1 \\
\hline Dolgozom. & 17,8 & 23,2 & 24,7 & 22,2 \\
\hline $\begin{array}{l}\text { Kedvtelésből böngészek az } \\
\text { interneten. }\end{array}$ & 3,9 & 9,8 & 10,4 & 8,2 \\
\hline Könyvet/ újságot olvasok. & 6,5 & 8,5 & 11,2 & 8,9 \\
\hline Pihenek. & 9,9 & 13,4 & 13,1 & 12,2 \\
\hline Egyéb. & 25,0 & 20,4 & 19,1 & 21,3 \\
\hline
\end{tabular}

9. táblázat. Szülői tevékenységek a gyermekük IKT-eszköz használata közben (százalékos gyakoriság)

\section{Diszkusszió}

A következőkben az óvodáskorú gyermekek IKT-eszközhasználatára vonatkozó vizsgálatunk főbb eredményeit értelmezzük és rámutatunk az azokban rejlő pedagógiai lehetőségekre. Továbbá felvázoljuk azokat a kérdéseket, amelyek további fontos kutatási irányokat jelölhetnek ki a témában.

Eredményeink szerint eszköz-hozzáférés tekintetében nincs digitális szakadék a vizsgált otthonok/családok között, hiszen minden, a vizsgálatban részt vett családban van legalább egy a felsorolt IKT-eszközök (számítógép/laptop, tablet, okostelefon) közül, továbbá az otthonok több mint fele (61,1\%) technológia-gazdagnak mondható, hiszen ezek a családok több digitális eszközzel is rendelkeznek. Ugyanakkor az is látszik, hogy a háztartások leginkább okostelefonnal vannak ellátva, 72,5\%-ukban legkevesebb két készülék található. A másik vizsgált érintőképernyős eszköz, a tablet, előfordulása kevésbé gyakori, a háztartások valamivel több mint egyharmada (36,1\%) nélkülözi ezeket.

Adataink azt is megmutatták, hogy a vizsgált óvodáskorúak közel egyharmadának (31,7\%) van saját IKTeszköze és a nagycsoportos gyermekek nagyobb arányának van saját IKT-eszköze, mint fiatalabb társaiknak. Ez arra utal, hogy minél idősebb a gyermek, a szülők annál nyitottabbak gyermekeik eszközbirtoklása tekintetében. Kérdés persze, hogy a saját eszköz egyúttal nagyobb szabadságot, illetve ellenőrzést, szülői felügyelet nélküli eszközhasználatot is takar-e egyben? Jelenti-e azt, hogy a szülók rábízzák a gyermekre a használat gyakoriságát, időtartamát és tartalmát is? 
Adataink azt is megmutatták, hogy a technologizált környezetben élő gyermekek döntő többsége $(81,65 \%)$ használ valamilyen infokommunikációs eszközt, és csak közel ötödük (18,36\%) nem teszi ezt. A szülők válaszai alapján mind az érintő-, mind a nem érintőképernyős eszközök jelen vannak az óvodáskorúak életében, de valamivel több gyermek használ okostelefont és tabletet, mint számítógépet vagy laptopot. Az érintőképernyős eszközök közül az okostelefon a legnépszerübb, a gyermekek leginkább ezt az eszközt használják minden korcsoportban. Ezek az adatok összhangban vannak az NMHH (2018) vizsgálatából származó információkkal. Az is figyelemre méltó eredmény, hogy a vizsgált gyermekek IKT-eszközhasználatának időtartama között gyenge, azonban hasonló erősségű a kapcsolat, amely arra utal, hogy ha a gyermek használja valamelyik eszközt, azo nos valószínúséggel használja a másik kettőt is.

Tehát eredményeink megerősítik, hogy a pedagógusoknak, gyermeknevelésben érintetteknek számolniuk kell az óvodáskorú (esetünkben 3-7 éves korosztály) gyermekek IKT-eszközhasználatával, valamint annak hatásaival. Azonban az is figyelemre méltó, hogy a digitalizált háztartások számottevő részében valami oknál fogva, feltételezhetően a szülők döntése, értékválasztása miatt, nincs jelen az IKT-eszköz az óvodáskorú gyermek mindennapjaiban, életében. Ezt a tendenciát a nevelésben érintetteknek mindenképpen figyelembe kell venniük, hiszen a szülőkkel való egyeztetés, tájékoztatás Nagy (2018) ajánlása szerint mindenképpen szükséges az eszközök csoportszobai tevékenységekbe való integrálása előtt. A párbeszédhez tudnunk kell, hogy mitől függhet az IKT-eszközök gyermekek életébe való beengedése. Ebben szerepet játszhat a szülők iskolai végzettsége, azonban esetünkben a gyermekek IKT-eszközhasználata nem függ a szülők iskolai végzettségétől, tehát más tényezőkben kell keresnünk a közös kommunikációs platform alapjait.

A szülők IKT-eszközökhöz való viszonyulása, eszközhasználatának gyakorisága, megnyilvánulási formája mintául szolgálhat a gyermekek számára. Legyen annak célja munka vagy szórakozás, majdnem minden válaszadó szülő (98,3\%) naponta használja okostelefonját, a képernyőidő átlagosan heti 8,5 óra. Ehhez természetesen hozzáadódik a többi eszköz használatával eltöltött idő is. Azok a gyermekek, akikről szüleik azt nyilatkozták, hogy használnak IKT-eszközöket, hetente átlagosan 5,1 órát használják azt. Ez az idő a gyermekek 1016\%-a körében (csoportonként eltérő) a hét minden napjára elosztva jelenik meg különböző eszközökön. Ha ezt összevetjük az NMHH 2018-ban közölt, a három éven aluliakra vonatkozó adataival, akkor láthatjuk, hogy az óvodáskorúak napi képernyőideje körülbelül napi 10-15 perccel több, mint fiatalabb társaik internethasználattal töltött ideje. Azt is megállapítottuk, hogy a gyermek életkorával nő a heti átlagos képernyőidő is. Tehát nem csak az IKT-eszközök repertoárja és a saját IKT-eszközök száma több az idősebb korosztályban, de az életkor előrehaladtával a képernyő előtt eltöltött idő is nő. Ezeket a tendenciákat összegzik Holloway és munkatársai (2013) is. A kisgyermekek heti képernyőideje fontos pedagógiai kérdéseket vet fel, főként, ha arra gondolunk, hogy az otthoni eszközhasználat hétköznapokon vagy a reggeli, az óvoda előtti, illetve az óvodába készülődés ideje alatt és/vagy az esti órákban valósul meg, amennyiben napi szinten jelen van. Kérdés, hogy az eszköz által közvetített ingergazdag tartalom után hogyan, mivel lehet lekötni a gyermek figyelmét, vagy felkelteni érdeklődését hagyományos pedagógiai eszközökkel, illetve hogyan befolyásolja az eszközhasználat a gyermek kikapcsolódását, pihenését, alvását.

Adataink adalékul szolgálnak a szülő eszközhasználatának minta-értékére is, hiszen a szülő okostelefonnal és számítógépezéssel eltöltött ideje összefügg a gyermek számítógépezéssel töltött idejével, de szignifikáns kapcsolatra bukkantunk a szülő eszközhasználatának időtartama és a gyermek egyéb IKT-eszközhasználattal eltöltött ideje között is. További fontos információ, hogy míg a szülő eszközhasználatának időtartama igen, iskolai végzettsége nem befolyásolja a gyermek eszközhasználatának időtartamát. A mintaadás fontosságának 
tudatosítása a szülőkben fontos pedagógiai eszköz lehet az új generáció eszközhasználatának formálásában, a képernyőidő optimalizálásában, illetve annak nem kívánt hatásai mérséklésében.

Szintén fontos kérdések, hogy mivel töltik a gyermekek a képernyő előtt az időt, milyen tartalmakat fo gyasztanak, illetve a szülók ebben milyen mértékben, hogyan vesznek részt, illetve kontrollálják a gyermekük eszközhasználatát. A szülő-gyermek közös tevékenység, az olvasottak, látottak, hallottak, történtek megbeszélése ugyanis számos területen jótékony hatást gyakorol a gyermek fejlődésére (Aram, 2008). E tekintetben kevés bizakodásra ad okot, hogy a szülők leggyakrabban valamilyen munkát végeznek, miközben a gyermekük IKT-eszközzel foglalja el magát, és leggyakrabban azért adják gyermekük kezébe valamelyik okoseszközt, hogy szórakozzon (37,4\%), másik két felkínált lehetőséget, hogy a "fejlődjön” és a "lefoglalja magát” mint célt, kisebb, de közel azonos arányban választják (21,3\% és 20\%). A gyermekek a heti átlag 5,1 okoseszközzel töltött órát leginkább mese és film nézésére, játszásra, zenehallgatásra és színezésre fordítják. Probléma lehet azonban, hogy az elérhető játékok elsősorban piaci igényeket szolgálnak, gyakran nem a gyermekek életkori sajátosságainak figyelembevételével fejlesztik azokat, s jellemzően szakértői (pedagógus és/vagy pszichológus) hátteret nélkülöznek. Mivel a magyar nyelvú fejlesztő alkalmazások száma erősen korlátozott, fontos lehet egy egységes, közösen kialakított szempontrendszer felállítása a pedagógusok és szülők részére egyaránt.

Elemzéseink arra is rámutattak, hogy a gyermekek életkorának előrehaladtával folyamatosan bővül az internetes tevékenységek köre. Kérdés, hogy felkészült-e a gyermek az internettel befogadni és feldolgozni a felnőtt világ minden pozitivumát és negatívumát, illetve hogyan segítheti a megértést és feldolgozást a szülő és az óvodapedagógus, valamint a tágabb közösség. Fontos megemlíteni, hogy egy nemrég életre hívott tengerentúli mozgalom, a Screenagers egyenesen közösségi feladatnak tekinti az arany középút megtalálását az eszközhasználat tekintetében. Jó hír, hogy a megkérdezett szülők többsége tudatos gyermeke okoseszköz-használata kapcsán, többségük ellenőrzi a fogyasztott tartalmakat, időkorlátot szab és időközönként közösen használja gyermekével az eszközt, nyitottnak túnnek a tudatosításra, a párbeszédre. Kérdés azonban, hogy a szülők mit és hogyan kommunikálnak a gyermek felé a tartalom és eszközhasználat kapcsán, kinek mi az érték, és milyen mértékủ használat számít függőségnek?

Adataink egybecsengenek Holloway, Green és Livingstone (2013) jelentésében foglaltakkal, mely szerint jellemző szülői magatartás a gyermekről való posztolás. Vajon tudják-e a szülők, hogy ez hazánkban is jogsértőnek minősül, és tisztában vannak-e azzal, hogy miért. Ugyancsak figyelemre méltó szülői viselkedés az is, hogy a szülők felhasználják az okoseszközöket gyermekeik motiválására, gyakrabban büntetésére. Ez újabb kontextusban mutat rá az IKT-eszközök kisgyermekek mindennapjaiban játszott meghatározó szerepére. Kérdés, hogy az óvodapedagógusok szempontjából ez jó vagy rossz irány? Kiaknázható-e az okoseszköz motivációs forrásként a nevelés során?

Arra is kíváncsiak voltunk, hogy van-e összefüggés a szülő személyi jellemzői és a gyermekük eszközhasználata között. Adataink szerint a szülő neme csak egy állítás esetében differenciál: a férfiak inkább jutalmazzák a gyermeküket IKT-eszközök használatával, mint a nők. A szülő iskolai végzettsége pedig alapvetően meghatározza azt, hogy gyermeke hogyan, milyen körülmények, feltételek mellett használja az IKT-eszközt. Bár a témát más szempontból közelítettük meg, adataink összecsengenek Konok (2018) eredményeivel. 


\section{Összegzés}

Az óvodáskorú gyermekek IKT-használatára vonatkozó nagymintás vizsgálatunk mind elméleti, mind gyakorlati, pedagógiai vonatkozásban hiányt tölt be a hazai kutatások között. Eredményeink megmutatták, hogy a vizs gált óvodáskorú gyermekek döntő többsége technologizált környezetben nő fel, és egy részük maga is rendel kezik IKT-eszközzel. Ebben a korosztályban még nem igazán jellemző a napi szintű eszközhasználat, azonban a szülők válaszai rámutattak, hogy a fogyasztott tartalmak igen széles skálán mozognak. A szülők válaszai leképe zik az évek óta tartó vitát az eszközök vélt vagy valós, jótékony vagy káros hatásáról, hiszen a vizsgált gyerme kek egy része egyáltalán nem használ IKT-eszközt, annak ellenére, hogy legalább egy darab van minden háztartásban. Az emögött meghúzódó okok, érvek feltárása fontos feladatunk. Annál is inkább, mivel eredmények azt jelzik, hogy a szülő fontos csatorna lehet a gyermekek eszközhasználatának alakításában. Az óvodapedagógusok és szülők folyamatos párbeszéde, a legújabb tudományos eredményekről való eszmecsere fontos részét képezheti a fogadóóráknak, szülői esteknek, ezzel támogatva egymás munkáját. Az adatok - a Digitális Oktatási Stratégiával összhangban - felhívják a figyelmet a pedagógusok digitális ismeretei bővítésének szükségességére is. Továbbá a tartalomfogyasztásra vonatkozó új ismeretek hozzájárulhatnak a pedagógiai tevékenységek, módszerek kibővítéséhez, megújításához.

\section{Irodalom}

1. Adolescent Brain Cognitive Development (2019, June 02). Retrieved from https://abcdstudy.org/

2. Antalóczy, T., Pörczi, Zs. \& Vaskuti, G. (2012). Óvodások távirányítóval. Média-és filmfogyasztás a legifjabb nemzedékek körében. Kultúra és Közösség, 3(1-2), 143-153.

Retrieved from http://www.kulturaeskozosseg.hu/pdf/2012/1/KEK\%202012_1_13.pdf

3. Aram, D. (2008). Predictors of maternal writing mediation to kindergartners: Analysis via a twins study. In R. N. Ramirez (Ed.), Family relations issues and challenges (pp. 43-68). NY: Nova Science Publishers.

4. Arnott, L. (Ed.) (2017). Digital technologies and learning in the early years. London: SAGE Publications.

5. Bassok, A., Finch, J., Lee, R., Reardon, S. \& Waldfogel, J. (2016). Socioeconomic Gaps in Early Childhood Experiences: 1998 to 2010. AERA Open July-September, 3, 1-22. doi: 10.1177/2332858416653924

6. Calvert, S. L., Rideout, V.J., Woolard, J. L., Barr, R. F. \& Strouse, G. A. (2005). Age, ethnicity, and socioeconomic patterns in early computer use: A national survey. American Behavioral Scientist, 48(5), 590-607.

7. Canadian Paediatric Society Digital Health Task Force (2017). Screen time and young children: Promoting health and development in a digital world. Paediatric Child Health, 22(8), 461-468. Retrieved from https://doi.org/10.1093/pch/pxx123

8. Chassiakos, Y. L., Radesky, J., Christakis, D., Moreno, M. A., \& Cross, C. (2016). Council on Communications and Media. Children and Adolescents and Digital Media. Pediatrics. 138(5). doi: 10.1542/ peds.2016-2593

9. Magyarország Digitális Oktatási Stratégiája (MDOS). Retrieved from https://www.kormany.hu/download/0/cc/d0000/MDO.pdf

10. Dorner, L., Hatvani, A., Taskó, T. Soltész, P., Estefánné Varga, M. \& Dávid, M. (2016). IKT-használat 10-18 éveseknél egy IKT-eszközhasználati kérdöív bemutatása. Magyar Pszichológiai Szemle, 71(1-2), 25-56. Retrieved from doi: 10.1556/0016.2016.71.1.2.

11. Fáyné Dombi, A., Hódi, Á. \& Kiss, R. (2016). IKT az óvodában: kihívások és lehetőségek. Magyar Pedagógia, 116(1), 91-117. Retrieved from doi: 10.17670/Mped.2016.1.91 
12. Harris, C., Straker, L., \& Pollock, C. (2017). A socioeconomic related 'digital divide' exists in how, not if, young people use computers. PLOS ONE, 12(3): e0175011. Retrieved from https://doi.org/10.1371/journal.pone.0175011

13. Holloway, D., Green, L. \& Livingstone, S. (2013). Zero to eight. Young children and their internet use. London: LSE.

14. Konok, V. (2018). Digital parenting style and role modelling: parental influences on children's use of mobile touch screen devices. Journal of Children and Media. Under revision

15. Központi Statisztikai Hivatal (KSH, 2014). Retrieved from https://www.ksh.hu/docs/hun/xstadat/xstadat_eves/i_oni006.html

16. Központi Statisztikai Hivatal (KSH, 2017). Retrieved from https://www.ksh.hu/docs/hun/xstadat/xstadat_eves/i_oni017.html

17. Livingstone, S., Haddon, L., Görzig, A. \& Ólafsson, K. (2012). Risks and safety on the internet: the perspective of European children: full findings and policy implications from the EU Kids Online survey of 9-16 year olds and their parents in 25 countries. EU Kids Online. London: EU Kids Online Network.

18. M. Fazekas, Á. \& Cs. Czachesz, E. (2011): Középiskolás tanulók számítógép- és internethasználati szokásai. Iskolakultúra, 21(8-9), 120-34.

19. Molnár, Gy. (2011). Az információs-kommunikációs technológiák hatása a tanulásra és oktatásra. Magyar Tudomány, 9, 1038-1047.

20. Nagy, I. M. (2018). Játékos IKT az óvodában. Módszertani kalauz az alapoktól a megvalósításig. Budapest: Neteducatio Kft.

21. Nemzeti Média- és Hírközlési Hatóság (NMHH, 2018). A hároméven aluli gyermekek médiahasználati szokásai.

Retrieved from http://nmhh.hu/dokumentum/195599/3_even_aluliak_mediahasznalata.pdf

22. Nikolopoulou, K., Gialamas, V. \& Batsuata, M. (2010). Young children's access to and use of ICT at home. Review of Science, Mathematics and ICT Education, 4(1), 25-40.

23. Pintér, M. (2016). Milyen tapasztalatokkal kerül az alfa-generáció az iskolába?

Új Köznevelés, 72(8). Retrieved from http://folyoiratok.ofi.hu/uj-kozneveles/milyen-tapasztalatokkalkerul-az-alfa-generacio-az-iskolaba

24. Pintér, M. T. (2016). Infokommunikáció használata a tanulásban Elméleti megközelítés az oktatásinformatikai készségek fejlesztéséhez. Gyermeknevelés, 4(2), 11-23.

25. Plowman, L., McPake, J. \& Stephen, C. (2010). The technologisation of childhood? Young children and technology in the home. Children \& Society, 24(1), 63-74.

26. Prievara, D. K. \& Pikó, B. (2015). Az interneten eltöltött idő és a problémás használat háttértényezőinek vizsgálata fiatalok körében. Iskolakultúra, 25(11), 90-102. doi: 10.17543/ISKKULT.2015.11.90

27. Rathbun, A. H., West, J. \& Hausken, E. G. (2003). Young Children's Access to Computers in the Home and at School in 1999 and 2000. Washington, DC: US Department of Education, National Center for Education Statistics.

28. Sari, B., Takács, K. \& Bus, A. G. (2017). What are we downloading for our children? Best-selling children's apps in four European countries. Journal of Early Childhood Literacy, doi: 10.1177/1468798417744057

29. Straker, L., Pollock, C., Zubrick, S. \& Kurinczuk, J. (2006). The association between information and communication technology exposure and physical activity, musculoskeletal and visual symptoms and socio-economic status in 5-year-olds. Child: Care, Health and Development, 32(3), 343-351.

30. Tatai, Cs. \& Kovács, R. R. (2016). Az Y és a Z generációk számítógép- és internethasználati szokásai, az elektronikus zaklatás jelensége. Szociálpedagógia, 4(1-2), 33-47.

31. Viner, R., Davie, M. \& Firth, A. (2019). The health impacts of screen time: a guide for clinicians and parents. Royal College of Paediatrics and Child Health.

32. Woo, E. H., White, P. \& Lai, C. W. (2016). Impact of information and communication technology on child health. Journal of paediatrics and child health, 52(6), 590-594. 


\section{Kindergarteners' ICT Use at Home - Parental Role Modeling and Engagement}

The expansion of information and communication technologies (ICT) has brought along an increase in the number of research focusing on the use and impact of ICT. Samples of these studies were mostly drawn from school-aged and older populations, so there is hardly any information on kindergarten aged children. More specifically, current data from large-scale studies on kindergarteners' and their parents' ICT use are not available. Therefore, the objectives of the present study were to examine (1) the ICT kindergarteners use at home, (2) the frequency of use and (3) screentime, and (4) the extent of parental engagement and control. In addition, we aimed at examining the relationship between parental education and children's ICT use. Our findings show that the vast majority of kindergarteners grow up in a technologically rich household, and some of them have their own ICT. In this age group, the daily use of ICT is not prevalent, but parents' responses have revealed that the children consume a very wide range of content on the internet. Parents' responses also reflect the multiple-year-long debate about the perceived or real beneficial or harmful effects of devices, as some of the children do not use ICT at all, even though they have at least one gadget in every household. Our data have shown that the permission to use a child's device and its duration and frequency is not, however, parental control is associated with parental education. Our results also point to the importance of parental role modeling, as the extent of children's ICT use is related to the extent of the parents' device use.

Keywords: ICT, kindergarteners, parents, screen time, content consumption, socioeconomic status 